\title{
Structural analysis of earth construction's vaults: Case of underground tombs of Chogha Zanbil
}

\author{
Sara Hosseini (Main Author) \\ Department of Conservation and Restoration, Islamic Azad University, Central Tehran Branch \\ Imam Hassan Ave., Pounak, Tehran (Iran) \\ s.hosseini64@gmail.com \\ http://rcid.org/0000-0001-6493-1101
}

Hamed Niroumand (Corresponding Author)

Department of Civil Engineering, Buein Zahra Technical University

Buein Zahra, Qazvin (Iran)

Quantitative Archaeology Laboratory, University at Autonoma Barcelona

Campus de la UAB, Plaça Cívica, 08193 Bellaterra, Barcelona (Spain)

niroumand.mrud@gmail.com

https://orcid.org/0000-0001-7765-9581

\section{Arzuhan Burcu Gültekin}

Department of Civil Engineering, Faculty of Technology, Gazi University

Yenimahalle, Ankara (Turkey)

arzuhanburcu@gazi.edu.tr

https://orcid.org/0000-0003-1246-6468

\section{Juan Antonio Barceló}

Quantitative Archaeology Laboratory, University at Autonoma Barcelona

Campus de la UAB, Plaça Cívica, 08193 Bellaterra, Barcelona (Spain)

juanantonio.barcelo@uab.cat

https://orcid.org/0000-0002-1580-471X

\section{Atasya Osmadi}

Construction Management Programme, School of Housing, Building and Planning, Universiti Sains Malaysia

11800 USM Penang, Penang (Malaysia)

a.osmadi@usm.my

https://orcid.org/0000-0002-4587-6642

\section{Fatemeh Mahdavi}

Department of Conservation and Restoration, Tehran University of Art

Valiasr St, Tehran (Iran)

mahpariya@yahoo.com

http://rcid.org/0000-0003-4041-2491

Manuscript Code: 13920

Date of Acceptance/Reception: 30.11.2020/14.05.2020

DOI: 10.7764/RDLC.19.3.366

\section{Abstract}

The 3300-year-old Chogha Zanbil is the largest and best-preserved five levelled pyramidal earth ziggurat outside Mesopotamia, which was inscribed on UNESCO's World Heritage List. Underground tombs of Chogha Zanbil are accepted as outstanding instances in Iran and consist of vaults, which are built with special methods by Elamite architects. In this context, the main purpose of this paper is to contribute to sustain the outstanding universal value of the Chogha Zanbil. For that purpose, this paper puts forward a structural analyse of the vaults of five Chogha Zanbil underground tombs, which were built inside the ground by brick, lime mortar, plaster and bitumen materials. Data for underground tombs and vaults were collected upon field observations and literature study. Finite-element methodology was used for structural analysis and SAP software was utilized to determine the way the forces are transmitted through the vaults, the conditions of bending moments, the shear forces. As a result, it has been observed that the bending in the vaults turns into pressure force that is perfectly resisted by bricks. In conclusion, it was ascertained that the vaults of the Chogha Zanbil underground tombs were built with the right techniques at that time, so that the vaults still have solid behaviour after thousands of years and remained completely healthy to this day.

Keywords: Chogha Zanbil, earth construction, structural analysis, underground tomb, vault. 
Culturally, Elamite civilization is the oldest historical period of the Iranian plateau, which was formed in the present southwestern region of Iran. The oldest inscriptions in connection with the presence of civilization called Elam, refer to Uruk's written inscription from the early third millennium BC (Amiet \& Potts, 2008). The name of Elam in Sumerian sources was written with an ideogram (NIM), often associated with a descriptive sign (KI) in the meaning of the earth and the country (after the name of the corresponding country) [NIM-KI]. The name of this land was first registered in the eighteenth century (BC) in Elamite sources in the form of "Hal Hatamti" or Hatamti (Hinz, 1964). The history of Elam is due to the historical division in Mesopotamia (Early Babylonian period, Middle Babylonian period, and Neo Babylonian period in the South and the early Assyrian period, the middle Assyrian period and neo Assyrian period), Egypt in the era of the Pharaohs (The era of the ancient dynasties, the middle dynasties and the new dynasties) and the Hittites in Asia. The early Elam era begins in the middle of the nineteenth century (BC) with the era of Sukkal-mah, and the new Elam era ends with the annexation of the land of Elam to the Achaemenid Empire (Majidzade, 2008). The interval between the reign of Elamites is divided into three periods as Old Elam (1500-2500 BC), Medieval Elam (Middle 1, 2, 3) (11001500 BC) and New Elam (New 1,2,3) (646-1100 BC).

The holy city of Dūr Untash belongs to the Medieval Elam period (1250 BC), and is located in the fertile plain of Shoshan in the southwest of Iran (Khuzestan province). This city was first identified in the early decades of the last century in aerial photographs, and the first excavations were carried out during the years 1935-1939 and 1946 by Roland de Mecquenem. The extensive excavation of this site, dating between 1951 and 1962, was carried out by Roman Ghirshman, an archaeologist and French scholar. This excavation provided a great deal of information on the structures of the city, and its adjacent temples and the historical issues of the Medieval Elam era (Tavakoli, 2006). According to this information, Dūr Untash had three fences (walls) and several gates, and all structures have been built between these fences. After the death of the king, some structures of the city were never completed.

For more than three thousand years, a ziggurat, which is known as Chogha Zanbil has been located in the centre of Dūr Untash (Figure 1.a). All the written documents from Chogha-Zanbil, between 5,000 and 6,000 bricks along with various other inscriptions, emphasize the fact that the city was new, and it was built under the command of Untash-Napirisha. Chogha Zanbil is regarded as an important place for many reasons. In terms of urban development and religious reformation, the achievements of Untash-Napirisha are unparalleled (McMahon \& Potts, 2001). With regards to material use, the structures built in Chogha Zanbil were made of clay and brick. A test by Professor R-Adams, director of the Eastern Chicago Association, revealed that all the bricks was made from the same soil that had been removed from the riverbank. There are three types of clays made in Chogha Zanbil area: raw clay, baked clay (brick) and raw clay with a mixture of broken bricks. The dimensions of the mentioned materials are $35 * 35 * 10 \mathrm{~cm}$ and $37.5 * 37.5 * 8 \mathrm{~cm}$ for baked clays (bricks), $40 * 40 * 10 \mathrm{~cm}$ and $41 * 41 * 10 \mathrm{~cm}$ for raw clays. Furthermore, due to its waterproof nature and its abundance in the southern region of Iran, mineral bitumen was used for water insulation in the gutters of Chogha Zanbil ziggurat, in the water structures and in the underground tombs. At present, in this area, three brick structures remain almost intact. One of them is the Chogha Zanbil ziggurat itself, which used to have 5 floors and now has 2 and a half floors. Second one is the water treatment plant that is a sound brick structure, and the third is the five underground tombs (Ghirshman, 1969).

The Chogha Zanbil collection presents a complete picture of government structures (palaces, tombs, temples) and residential buildings with a limited but plentiful variety, both in terms of plan and in terms of the use of materials. In 1979, Chogha Zanbil was listed on the World Heritage List by the United Nations Scientific and Cultural Organization (UNESCO) due to its exclusive features. The Chogha Zanbil ziggurat is created based on religious beliefs of the Elamite people and the authority of Untash Napirsha. This place is presented to two gods from the gods of Elam. These gods are Inshushinak (the protector of the city of Susa) and Napirisha (the Great God) (Afkhami, 2019).

The surface of the ziggurat is square, and the length of each side is 105 meters on the ground. It is likely that its height was 52 meters during its development. Currently, the tallest remaining part is about 25 meters above ground level. In Chogha Zanbil Ziggurat, which is in contrast to the known ziggurats in Mesopotamia (present Iraq) with the floors being built on each other, the floors are built inside each other and each floor is independently located on the ground (Figure 1.b). It is a massive and solid building made entirely of raw clay, and exterior parts are made of brick. According to the existing inscriptions, the temple is decorated with blue and green glazed bricks, interconnected circles and rhombuses with silver and golden brilliance. Moreover, golden and azure bricks have been shining above the ziggurat. Tubular glass rods, which were used to decorate the doors of temples, are also found in Chogha Zanbil, and they are known as the oldest tubular glass rods in the world (Salehvand, Shishegar \& Firoozmandi Shireh Jin, 2019). 
Figure 1. Ziggurat Chogha Zanbil (Iran). a) Geographic location of the Ziggurat Chogha Zanbil (Yordanov, Mostafavi, \& Scaioni, 2019). b) Aerial view of the Ziggurat Chogha Zanbil (Yordanov et al., 2019).
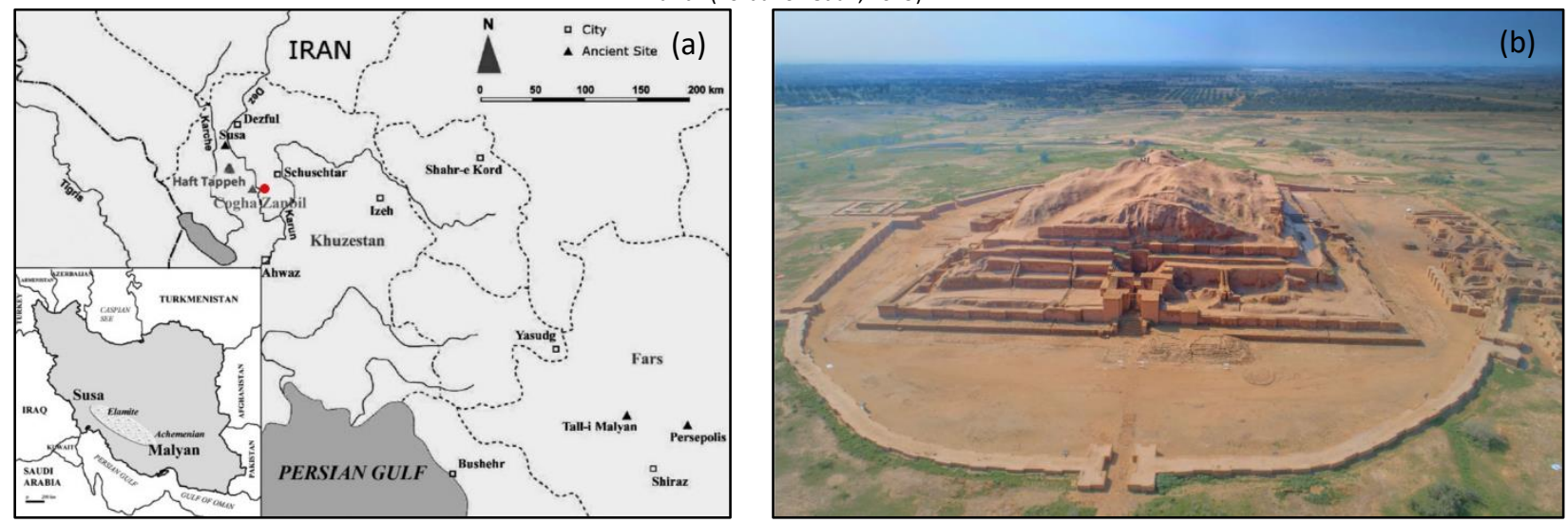

Description of the Problem

As the climate in most parts of Iran is warm and dry, many of the buildings have vault, arch and dome. In Iran's past architecture, lancet arch and round arch were both used. Especially before Islam, round arch was applied more. Iranians never used circle forms to build arches, because circle shape had some weaknesses, which put vaults in trouble. Arches were mostly in shape of elliptic. Type of arches was selected based on the type of structure. In the past, since glory was very important, arches with high altitude were used. The structural analysis of the arches used in Elam architecture is important because these arches are the parts of the first vaults built with local materials in Iranian architecture. The way these structures were built are of high importance. Many researchers have conducted many studies regarding mechanical properties of vault arches and sought for ways to analyse load-bearing masonry structures. However, none of them focused on the tombs of Chogha Zanbil area for making an analysis regarding to the materials of ancient vault arches.

State of the Art

In the context of the problem definition, the theoretical framework of this article is based on analysing the structure of the vaults in the underground tombs of the Chogha Zanbil area and determining how they still remained intact three thousand years after they were built. According to Flores-Ales et al. (2017), historical buildings, which were built with appropriate construction techniques at the time, have survived to the present day with appropriate conservation and maintenance efforts. In line with this observation, the main purpose of this study is to prove how the extraordinary universal value of the Chogha Zanbil underground tombs has been preserved to date through the structural analysis of the vaults.

Materials and Methods

\section{The Features of Chogha Zanbil Underground Tombs}

The people of Elam believed that people should be in the family after they died, so they buried the dead under the houses. Guessing this fact, the head of the Chogha Zanbil exploration team, French archaeologist Roman Ghirshman, had one of the palaces of Elam digged. As Ghirshman predicted, the crater of the Elam tombs was covered by bricks, plaster mortar and bitumen. The team opened the crater and passed through the stairs, which were in good condition, and discovered five tombs under the palace (Figure 2). This palace tombs complex is on the east side of the great royal gate and $250 \mathrm{~m}$ east of the Ziggurat area. Standing alone at the eastern entrance, this complex was built in four directions, similar to Ziggurat. 


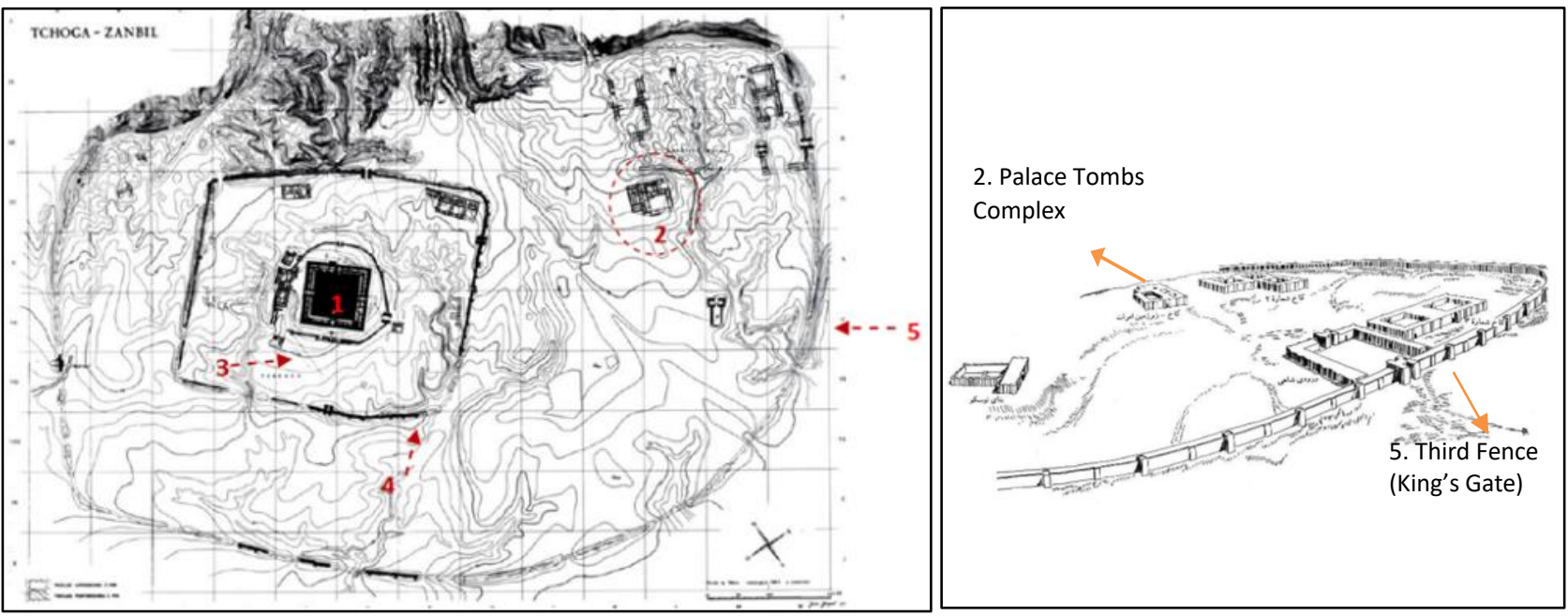

According to Figure 3, the palace building has some exits, three of which remain on the south-east side. The wall of the building is $70 \mathrm{~m}$ long and $56 \mathrm{~m}$ wide. The building is consisted of 3 courtyards, and 22 rooms in the ground floor, and 5 tombs on the basement floor. Figure 3 also illustrates the location of the underground tombs, which are located below the rooms, on the basement floor. A three-dimensional view of tombs collection and a perspective of one of the tombs is depicted in Figure 4.

All tombs have one or two rectangular rooms with arched roofs. The entrance of all of them has a staircase from the ground floor to the basement space inside the tombs, which are also arched. But in this paper, the focus is on the examination of the roof of the tombs. According to Roman Ghirshman, the arched-shaped vaults of the tombs did not contain any bricks that had been molded specifically for this purpose. All bricks used are simple type $35 * 35 * 10 \mathrm{~cm}$. The width of the tombs is 3.60 meters on the ground floor and the rise of the arches is 2.20 meters from the ground. In brickwork, each of the facade bricks is a few centimetres ahead of the previous brick. The radius of the arched vault is irregular because its effect and geometric trace are slightly broken at the point where the arch rises, and the two halves join. From the very beginning of the arch, the bricks become oblique on the basis of the rejection of the arc. However, the bricks that make up the rise are laid as straight as possible due to the large weight they have to bear (Young \& Ghirshman, 1969).

Brick vaults can withstand little tensile forces, it is important to design them in such a way that the maximum forces in the arch springers are compressive forces. As shown in Table 1, the vaults have a high rise. The structural shape of the vault plays a significant role in its retention. The higher the keystone, the more the total forces tend to be vertical, and therefore the load decomposition decreases horizontally. When the issue of the stability of the supports is raised, the use of a high-rise generator component is preferred. This is well observed in the case of underground tombs. Due to the fact that the shear force reaches the maximum on the upper sides of the vaults (extrados lines) and according to the behaviour of brick materials, the only way to control the existing shear force is to increase the thickness. The engineer has only artistically increased the thickness of the maximum shear force location to reduce costs, which has been a principled and engineering work. Regarding the control of the structure against the bending force, it is very important that the anchor created in the vaults turn into the compressive force, the bricks withstand the compressive force well, but they do not withstand the tensile force. Today for ordinary roofs (Square frame) rebar is used to control the tensile force generated by the bending anchor. Another point in these vaults is the uniform distribution of forces instead of sudden changes.

All five underground tombs subject to this study have remained healthy to this day. The only damage is that half of the tomb number 5 was destroyed, which is estimated to have been done maliciously. In Table 1 , the height, width and the angle of deviation of the various sections of the tomb vaults from the centre points are presented. 
Figure 3. Plan of the palace tombs complex revised from Young \& Ghirshman 1969 (Drawings by author).

Map Legend

Adobe wall

Brick wall

Brick ballast

$\square$ Platform

$\square$ Tomb No.1

$\square$ Tomb No.2

$\square$ Tomb No.3

$\square$ Tomb No.4

$\square$ Tomb No.5

p. Door

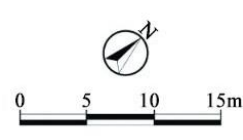

A

A

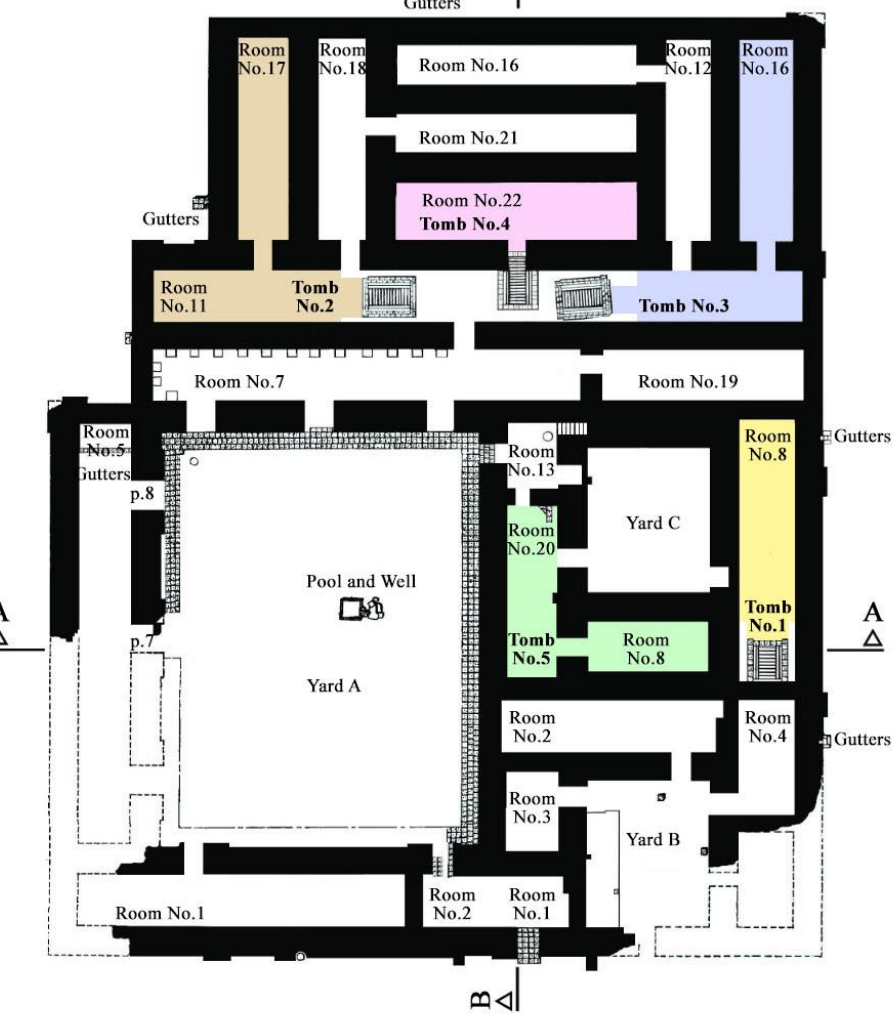

\section{$\underset{\text { Gutters }}{\oplus \triangleleft \mid}$}
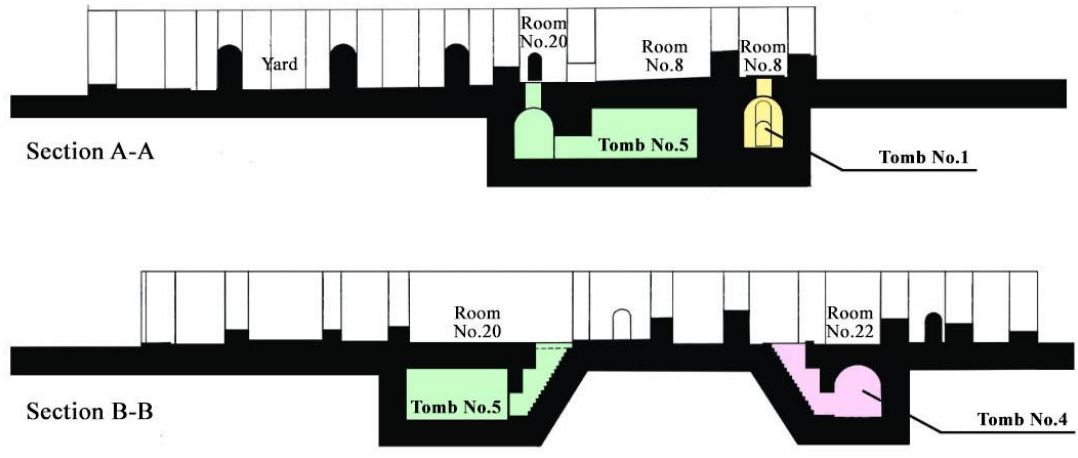

Figure 4. Views from the tombs. a) Three-dimensional tomb collection (Drawing by author). b) A perspective of one of the tombs (Drawing by author).
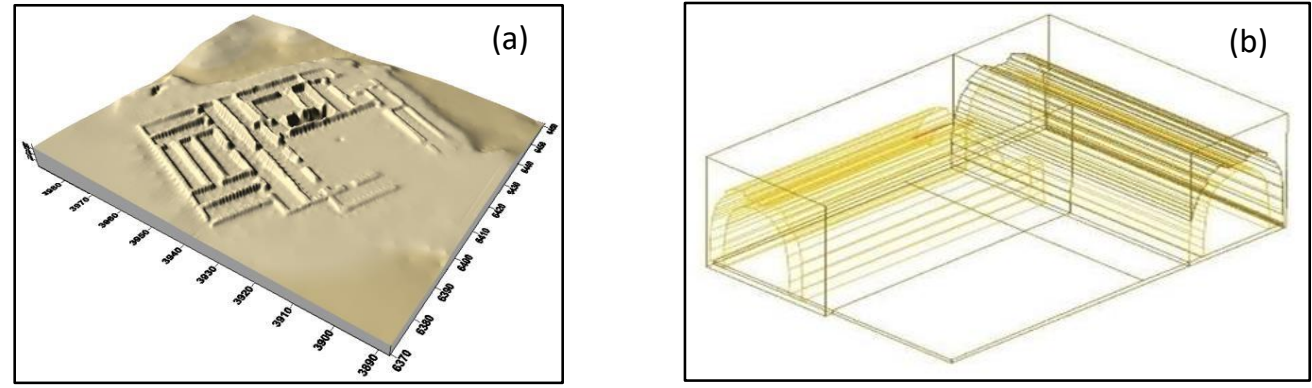
Table 1. Sizes and views of the vaults of underground tombs (Drawings by author).

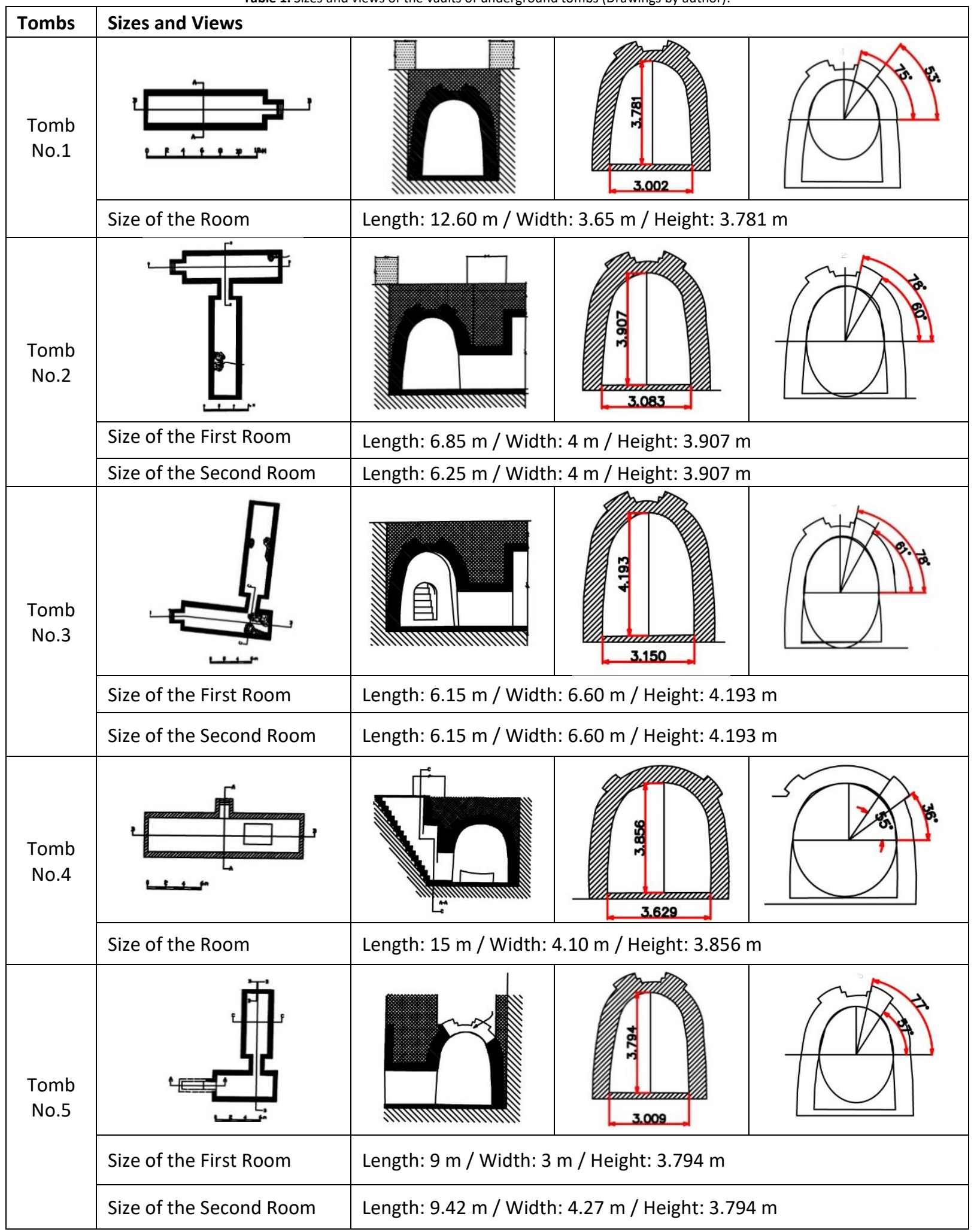

During the new Sumer-Akkad period, the burial ceremony in the Mesopotamian region was similar to Elamite ceremony. The monuments of their royal temples were made of brick and had arched staircase rooms. In the cellar of the tombs of ancient kings in Ur, there is a dome and crescent arches. Reports of this monument confirm that the tombs were built in several stages according to the burial ceremony. Chogha Zanbil underground tombs were also built based on beliefs in the afterlife. The two room groups were temples dedicated to Inshushinak, Susa's supreme god. One of the temples 
opened into the inner courtyard while the other outwards (Amiet, 2018). Considering the dimension and size of the temple, construction techniques and material type, these are made for important people like princes.

As presented in Table 2, the temple has two floors including a number of rooms on the ground floor and tombs in the basement (see Figure 3). It has three yards: Yard A, Yard B, and Yard C. According to Ghrishman findings during the excavation, all of the rooms in the ground floor had flat ceilings, while all the underground tombs had vault arches.

Table 2. Plans and sections of the tombs revised from Young \& Ghirshman 1969 (Drawings by author).

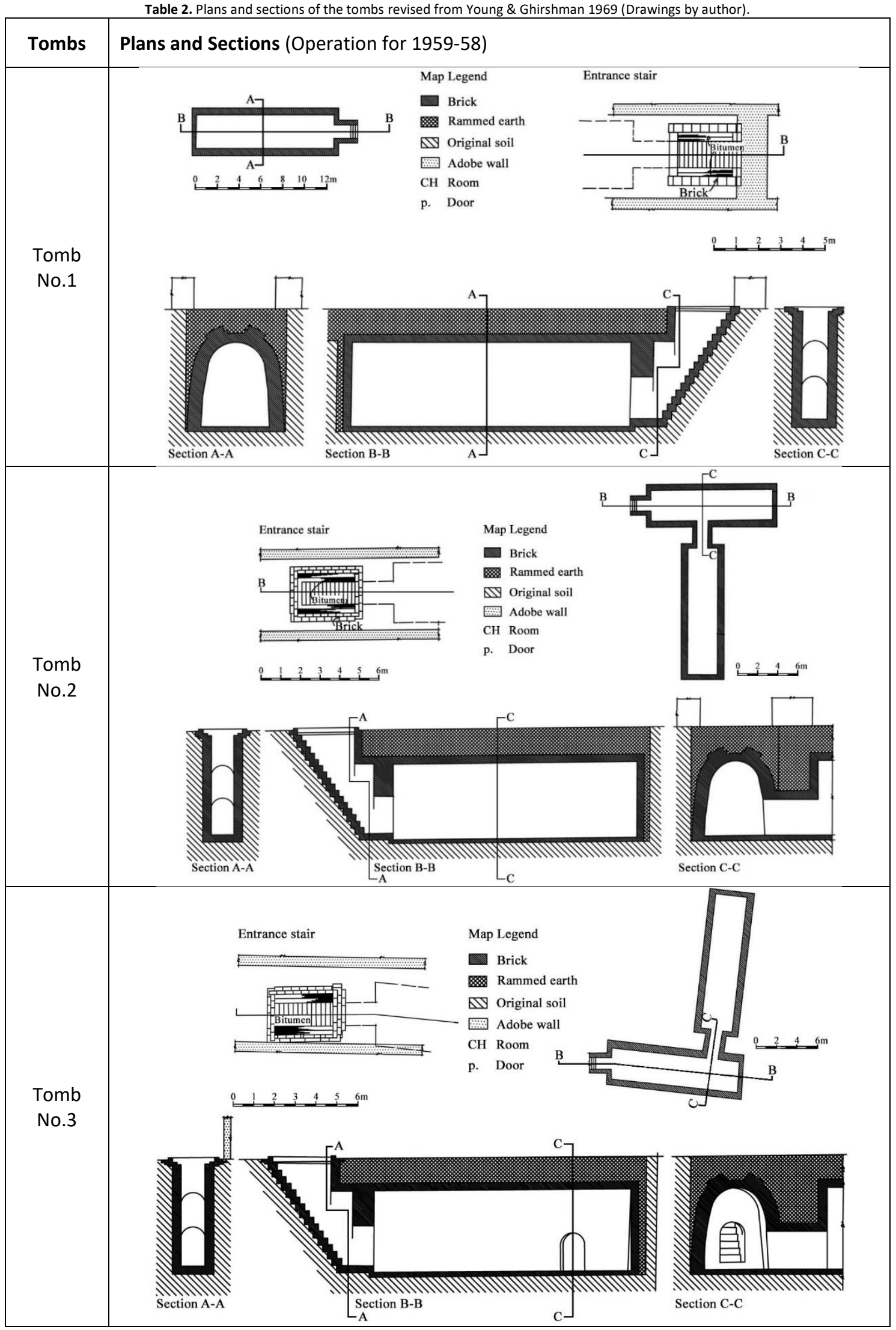




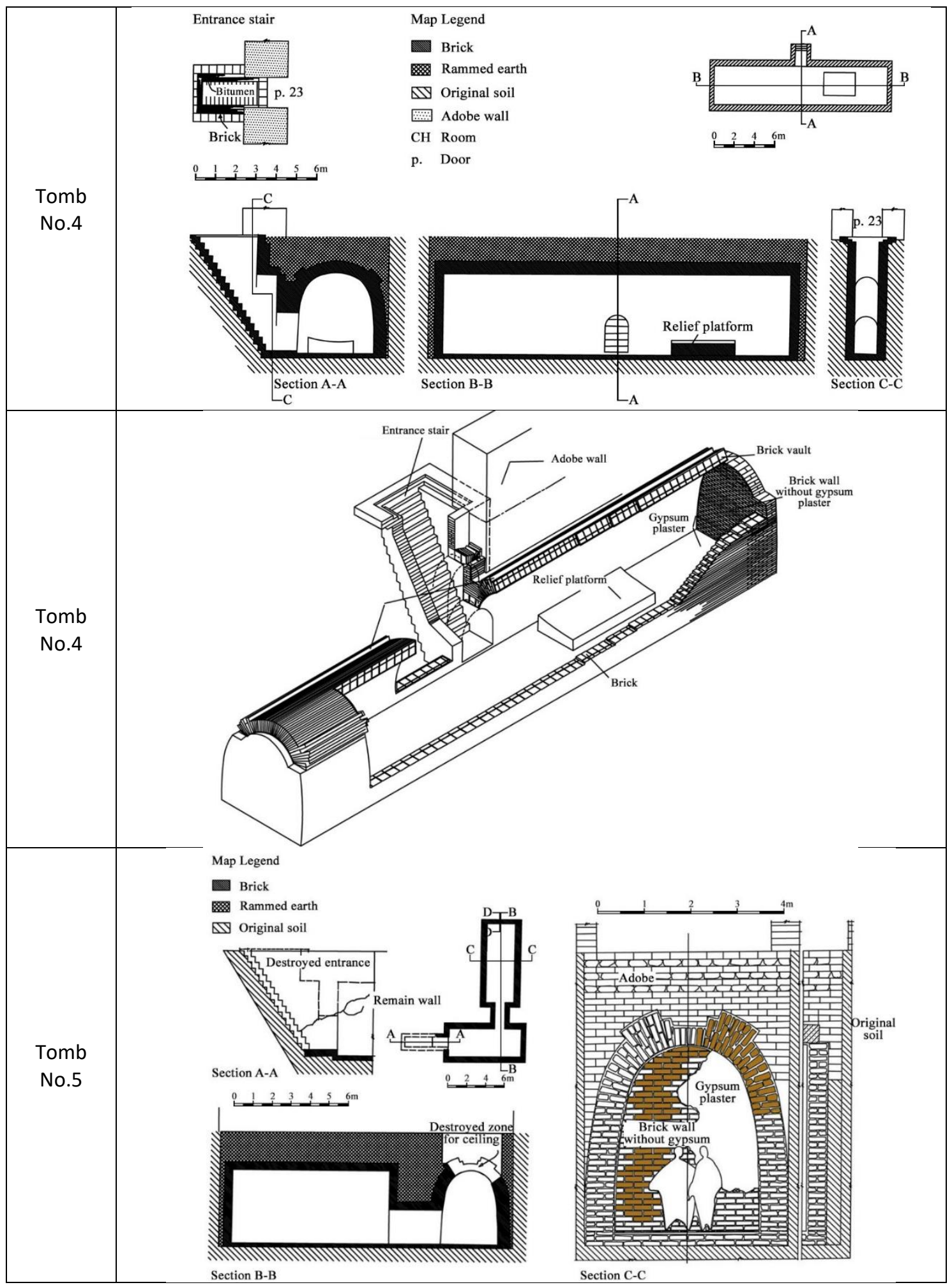

Brickwork can be clearly seen in the drawings of Ghirshman (Figure 5a-5c). All tombs had an entrance staircase that was completely blocked with bricks, mortar and bitumen during exploration. All surfaces of the tombs were covered with a layer of plaster made by hand from the floor to the ceiling. The fingerprints were obviously seen on the plaster. Such plaster inside the building indicates respect and importance. A height of about one meter on the top of the tomb is filled with a layer of soil and clay.

The plans of the five tombs differ from each other. There are three tombs in two rooms, and two tombs in one room. The bodies found inside them were burnt down, which is not a burial method observed in Elamite civilization until then. Due to the fact that multiple individuals were buried in most Elamit tombs, Zalaghi explains that they were reused multiple times, even if they were family tombs (Zalaghi, 2018). 
Other features of these vaults are their integrity from floor to ceiling (Figure $5 \mathrm{~b}$ ). The integrated construction of the vaults certainly helped them to protect them from external forces. As shown in Figure $5 b$, the vault is located to a great height in the soil, which prevents the opening of the vault from the extrados.

Figure 5. Views from tomb number 5. a) Tomb number 5 whose roof has fallen (Captured by author). b) Connection of the vault of tomb no.5 to the ground (Young \& Ghirshman, 1969). c) The roof of Tomb No. 5 part of which Gershman opened (Young \& Ghirshman, 1969)
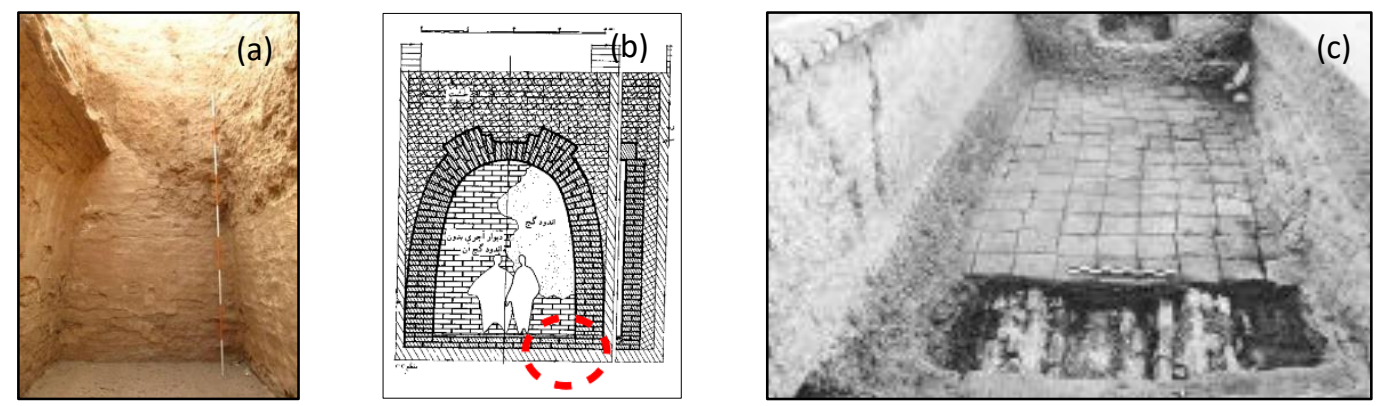

Due to the problems of protection and prevention, the insects, atmospheric precipitation and unauthorized diggers, the doors of all these tombs are blocked and covered with thatch at the moment. Therefore, it is not possible to take new photos of the doors. Photographs of the doors given in Figure $6 a-6 b-6 d$ were taken in previous years.

Figure 6. Views from the entrances of tomb number 5. a) Entrance of one of the tombs (Captured by author). b) Brickwork and plasterwork of the tombs (Captured by author). c) The current status of the tombs, which their entrance is covered (Captured by author). d) The entrance to the tombs on the ground (Young \& Ghirshman,
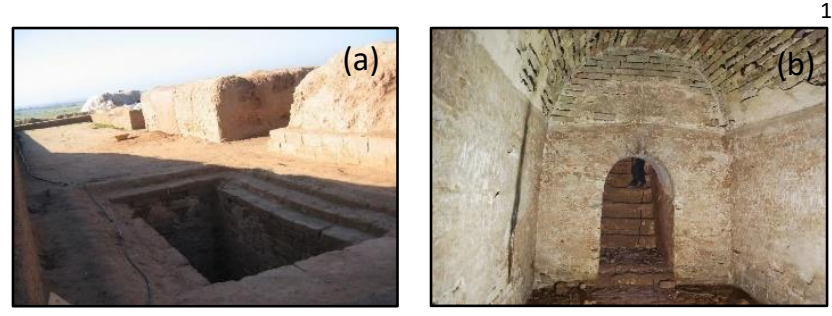
1969).

\section{The Construction Materials of Chogha Zanbil Underground Tombs}

Main construction material of the palace underground tombs is brick. The walls of the palace are made of bricks. The bricks used are of a simple type, without any molding. The colour of these bricks is a colour spectrum from cream to green-yellow. The inner texture of handmade bricks was formed as an example of the hand's pressure on the clay paste for compression in the molding process. If this pressure happens to be uniform, perfect texture is able to be obtained in brick. Normally, this texture is for the desired clay bricks and compressed ones. All of these bricks have a very rough surface texture and their porosity is very high. The connection between the bricks is provided with mortar. Two layers of plaster mortar and one layer of mineral bitumen were used, because this area was located underground and there was a possibility of water penetration inside it. The height of each mortar row is $1.5 \mathrm{~cm}$. The walls and arch-shaped vault are covered with a layer of $1.5 \mathrm{~cm}$ of lime, and then covered with plaster. Dimensions of the bricks used in tombs are $35 * 35 * 10 \mathrm{~cm}$. For the ingredient and component analysis of the tomb materials, XRD tests were performed by the author on the existing samples, and the mentioned percentages were obtained by these tests.

Brick: Explorations in the field have indicated that bricks of Chogha Zanbil area were of various types in terms of interior texture. According to tests, bricks made of soil around the river Dez had a good compressive strength. Furthermore, bricks that have dense texture were less damaged. All bricks had high porosity and had a level of roughness, except for inscribed bricks with a smooth texture. Chogha Zanbil bricks had a colour spectrum from yellow, brown, red to green. In some areas, bricks were moulded according to structural conditions, such as bricks used at the crown of the vault. According to the qualitative XRD test results, bricks consist of calcite, quartz, dolomite, gypsum and feldspar, which are the main components in the texture of brick samples. According to qualitative XRD test results, bricks consist of calcite, quartz, dolomite, gypsum and feldspar, which are the basic texture components of brick samples. In these tests, FTIR represents the properties of carbonate, nitrate and silicate compounds in the texture of brick samples. 
Chogha Zanbil Clay: Some clay samples were analysed by the Chicago Oriental Institute and as a result, it was determined that all the bricks were made from the soil taken from the shores of the river Dez. Millions of bricks were carried from the shore to the city by thousands of mules, donkeys and workers, and even the smallest fractured pieces were used. No furnace marks were found in the Chogha Zanbil area for brick production. This strengthens the possibility that the furnaces were buried under thick deposits or wood-fuelled temporary furnaces were used. The fact that furnace bricks and firebricks were made with a similar production technique in previous years strengthened this hypothesis (Figure 7a).

Mortar: Mortar is one of the most important components to bond the construction materials. Mortar type, raw material, construction technique and mortar treatment method should be carefully selected to ensure that the integrity of the structure is not impaired and structural connections are not weakened. The mortar used between the bricks comprises sulphate, carbonate, nitrate, silica and hydroxide compounds.

Plaster Mortar: Studies on samples show that plaster mortar consists mainly of plaster, inderite and some calcite. The constituents of plaster mortar are gypsum, inderite, quartz, calcite and feldspar. According to tests performed on plaster mortar samples, some of the samples have a high percentage of about $95 \%$ plaster and only a few impurities, including sand, clay or lime seeds. Some samples also have about $70 \%$ plaster content, and the rest of their composition are sand, clay and lime, respectively.

Bitumen: Before Chogha Zanbil, Elamites used bitumen mortar for the construction of their religious buildings in the city of Dur Untash and bitumen in the brickwork of their buildings in Susa. The bitumen used is known as the natural bitumen resulting from the outflow of oil from the reservoirs and the flow of the earth on the surface. The term "oil" was used as "pure" in the sense of anti-humidity in Persian language. Because of this feature, bitumen mortar was used in Chogha Zanbil area for spaces adjacent to water and for floor coverings of underground tombs. This bitumen mortar sample is mainly composed of well-groomed clay calcite, iron oxide and other organic materials. These samples include calcite, quartz and dark minerals. Identification of the mortars was made by petrography method. Using XRD-FTIR tests, the mineral was understood to contain calcite, quartz, feldspar and mica, and its organic fraction was hydrocarbon. Besides, it was found out to contain $65 \%$ lime, $20 \%$ sand, $11 \%$ oil and $5 \%$ straw (Hosini, 2002).

Lime mortar: Lime is a sticky material. It combines with the carbon dioxide of the air and hardens, thus forms calcium bicarbonate. It consists of rock-based materials such as lime, sand and gravel. Lime increases pressure resistance restricts the accumulation of the mortar and makes it more economical. Lime mortar offers good chemical stability and mechanical strength. However, its slow hardening and relatively long solidification pose a problem for the construction of the vaults (Figure $7 b$ ).

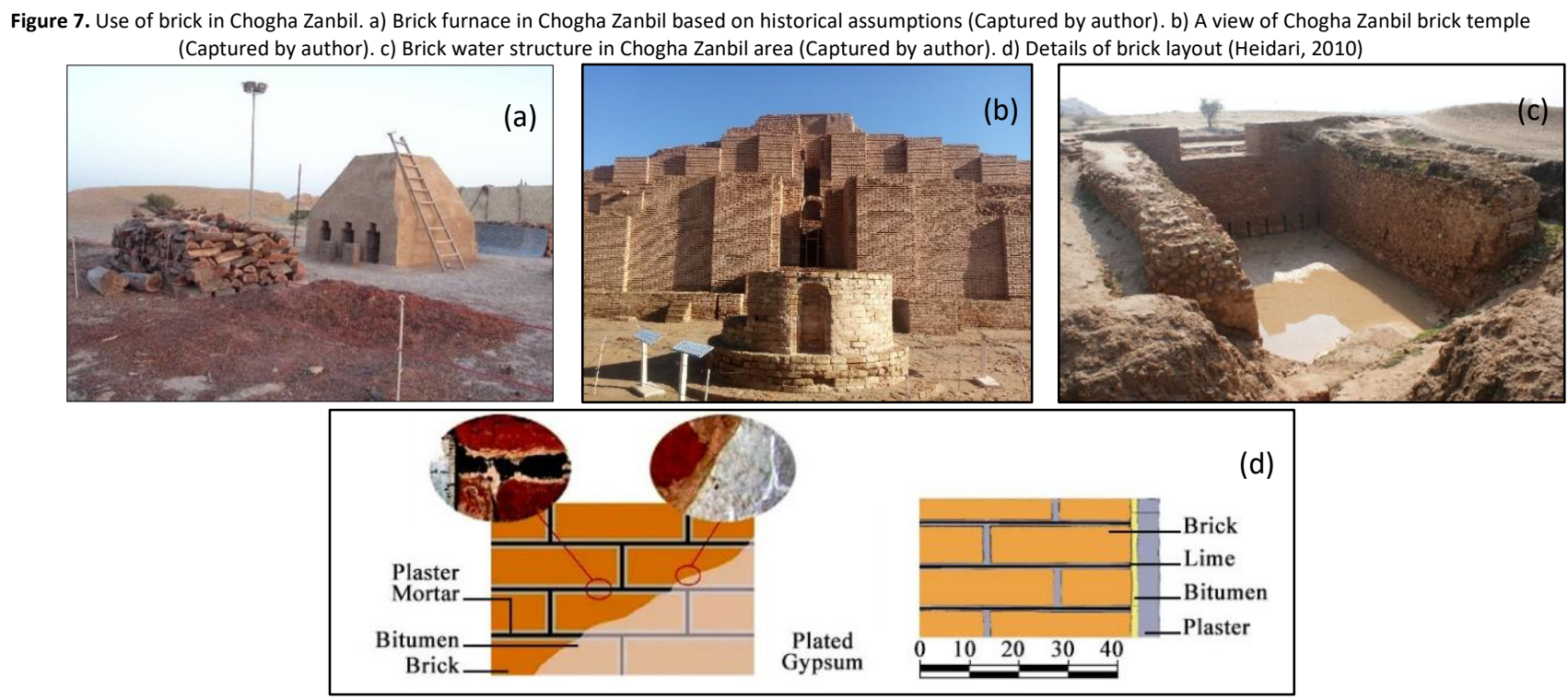




\section{The Methods for Structure of the Vaults of Chogha Zanbil Underground Tombs}

Based on architectural expressions, vault is a structural element consisting of one or more arches in direction of one axis or different axes on a surface between two walls under load, usually forming a ceiling or roof. In other words, vault is a three-dimensional arched construction to provide a space with a ceiling or roof. Each vault of Chogha Zanbil underground tombs was made of stone. The two tombs have one room and the other three have two vertical rooms. These tombs were constructed inside the earth; ultimately, they were surrounded by untouched soil.

In Chogha Zanbil explorations, it was understood that the Elam tombs were built in the thirteenth century BC and had vaults with parabolic brick arches. These were also used after the Chogha Zanbil era. Basically, vaults can be constructed by the following four methods:

Barrel method: In barrel method, the bricks are explicitly visible from the bottom and the side as a complete surface. Although this method has been accepted as having a good resistance, compared to soldier method has a lower resistance. The simplest Iranian vault is the barrel vault, which is the continuation of one type of arch in a certain direction. Due to the simple coating, it is sometimes called the tunnel vault. As shown in Table 3 , the barrel vault has the widest coverage in buildings with two continuous walls on both sides; such as water tanks, porches, galleries and rectangular shaped areas where their vaults are preferred to be uniform.

Mid-fill method: In mid-fill method, the bricks are used in the form of a blade, and the surface is completely visible from above and below.

Soldier method: In soldier method, the bricks are clearly seen in vertical axis, and in the form of complete surface in horizontal axis. Soldier method has more resistance than the other two methods.

Parabolic method: In parabolic method, low height (tardy), high height (steep) and normal (middle height) parabolic arches have no columns or covers. The first row of the brickwork starts from the surface level of earth ground, and with each row coming forward, the length of the span is reduced by tightening method. From the middle of the vault, by wedging the mortar behind it, there is torsion in brickwork. This is followed with identical soldier rows by bringing forward gradually till the construction of the vault is finished by grouping and tightening. Due to the shape of the arch, its resistance is very high and rarely fractures or pours. This resistance increases by adding to the height. In Table 3 , it can be seen how the force is distributed in barrel and parabolic vaults.

Table 3. Construction methods for the vaults of underground tombs (drawings revised from Zomorshidi, 2008) (photos captured by author).

\begin{tabular}{|c|c|c|c|}
\hline $\begin{array}{c}\text { Tomb No.1 } \\
\text { (Parabolic Vault) }\end{array}$ & $\begin{array}{c}\text { Tomb No.2 } \\
\text { (Parabolic Vault) }\end{array}$ & $\begin{array}{c}\text { Tomb No.3 } \\
\text { (Parabolic Vault) }\end{array}$ & Tomb No.5 \\
(Barrel Vault)
\end{tabular}

\section{The Elements for the Vaults of Chogha Zanbil Underground Tombs}

A vault has different elements, named according to the degree of deviation from the vault's central point (Figure 8). The element where the vault brakes outward and deviates by 22.5 degrees is called extrados. Voussoir is another element 
that the vault brakes inward and deviates 67.5 degrees. When the vault breaks outward at the top point, this is technically called as turned over.

In the construction of the vaults, the distance between the base and the extrados is usually applied with a width equal to 1.16 of the span sizes. From span to the angle of 45 degrees (middle side point), width is reduced by one brick. Until voussoir, again one brick is decreased from width of keystone. Similarly, from the voussoir to the keystone, one more brick is reduced from the vault.

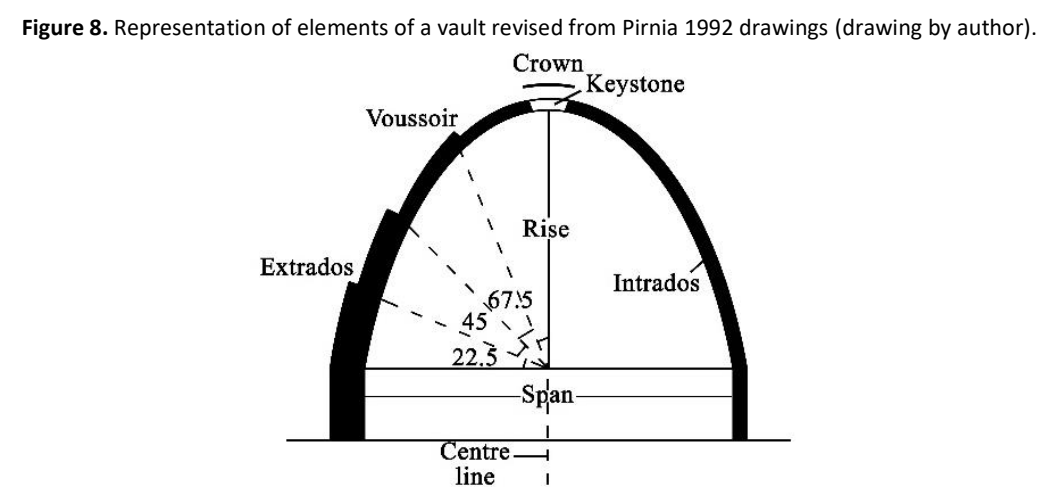

The generating element is defined by two characteristics, the crater and the crest, both of which define the equilibrium indices. The equilibrium indicator is obtained from the following equation:

$$
\text { Equation: } \quad l_{a}=2
$$

Distance between the two legs of a vault is called span ( $p$ ). The rise ( $r$ ) of the arch is the distance between the tip of the arch and the flat surface on the barber carrier. Selecting the coefficient as 2 ensures that la is equal to 1 in the case of a semicircular arch or full crescent. The tall rise happens when la $>1$ and the low rise when la $<1$ (Besenval, 2000). In Figure 9, the types of vaults according to la are presented.

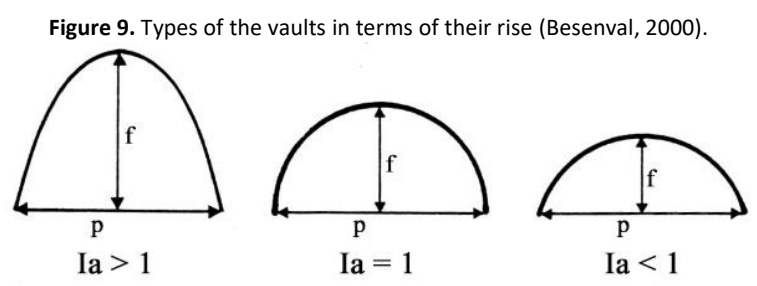

\section{The Analysis of Rise on the Vaults}

Since the clay vaults can withstand a low tensile force, it is important that they are designed in such a way as to form the most pressure forces in the impost of the vault (Golabchi \& Javani Dizchi, 2016). As in Table 4, it is clear that the arches are long. The structural form of the vault plays a significant role in its retention. According to Besenval, the higher the rise of the arch is, the forces tend to be vertical, and therefore the decomposition of loads decreases horizontally. Therefore, for the sustainability problem of the vaults, it is preferable to use a generating element with a high rise. This problem is well adhered to in the case of underground tombs. The width of the brickwork of the vaults and supports is one and a half bricks, excluding the waist level of the vaults. This level is in which 4 to 6 streaks of brickwork with the thickness of 2 to 2.5 have led to the advance of the arch. This feature, which is seen in all of the vaults, increases the stability of the dome, in correlation with the upper filler mass of the clay (Besenval, 2000). For the shaping of these arches, they have no effect on the walls without cover (mold holes, etc.). 
Table 4. Calculation of the rise for the vaults of underground tombs

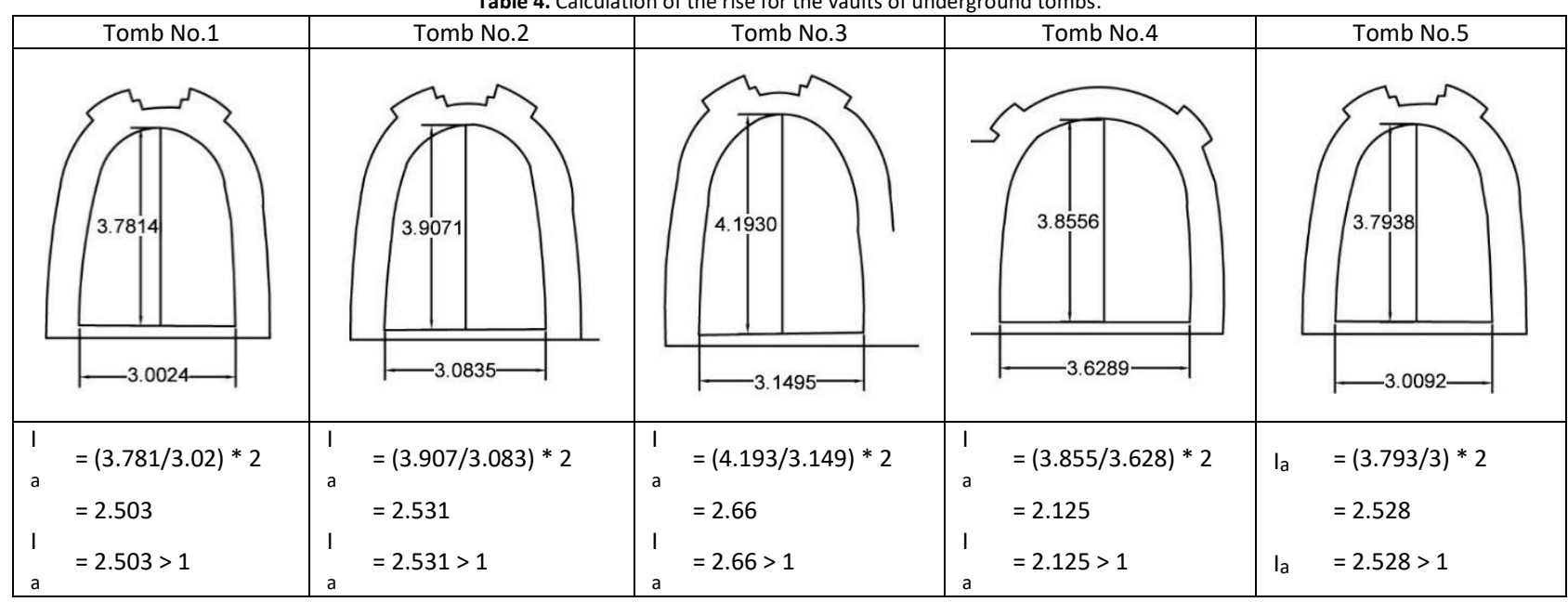

\section{The Structural Analysis of Loads on the Vaults}

According to R. Koldwey, underground arched tombs being stabilized by earthen gravity walls achieve a better stability than free standing ones (Koldwey, 1914). In another study by N. Haddad, the arched structures in the tomb of Eurydice, which belong to the Hellenistic period, were evaluated. In this study, he stated that the architect has used arch structures to be able to control the vertical load and distribute it in a better way (Naif, 2015). Likewise, vaults have different loads depending on the type of arch, brick arrangement and shape. In the vaults of the Chogha Zanbil underground tombs, the shape of the vaults is parabolic, and the arrangement of the bricks is vertical. When the bricks are vertical, it can be stated that the vault has better resistance in comparison to other types of arches in terms of brick layout. In this case, the forces act on the arch first from above, and then enter the bases and from there to the ground respectively. This force transfer occurs well when the load distribution occurs well, and the total forces does not come out of the wall but passes through the wall itself. Depending on the type of arch, the total force is differentiating. To control this situation in Iranian architecture, according to the shape of the arch and the arrangement of the bricks, the thickness of the walls was also different. In this framework, the thickness of Chogha Zanbil vaults is about $60 \mathrm{~cm}$, and they were built in the heart of the earth. Thereby the earth acts as a backrest and prevents any movement of the arch.

For the structural analysis of loads on the vaults being examined in this study, finite-element methodology was used. Besides, analyses were calculated in SAP software. According to probes over the vaults, each cubic meter of soil over the vaults is $1600 \mathrm{kN}$ (see Figure $5 \mathrm{c}$ ). In this study, the structural analysis of the vaults was carried out on the 10centimeter vault length. The brick flexibility in the projects is assumed to be $25000 \mathrm{mPa}$, which has no specific effect on the results. The load variations on each of the five tombs, according to the results of the structural analysis, are presented in Table 5 in terms of axial force, bending moment, and shear moment.

\begin{tabular}{|c|c|c|c|c|c|c|}
\hline Tombs & Axial Force & $\begin{array}{c}\text { Intensity of Axial } \\
\text { Force }\end{array}$ & $\begin{array}{l}\text { Bending } \\
\text { Moment }\end{array}$ & $\begin{array}{c}\text { Intensity of } \\
\text { Bending } \\
\text { Moment }\end{array}$ & Shear Moment & $\begin{array}{c}\text { Intensity of } \\
\text { Shear Moment }\end{array}$ \\
\hline $\begin{array}{l}\text { Tomb } \\
\text { No.1 }\end{array}$ & 贯 & & & & 春 & \\
\hline $\begin{array}{l}\text { Tomb } \\
\text { No.2 }\end{array}$ & + & & & & & \\
\hline & & & & & & \\
\hline
\end{tabular}




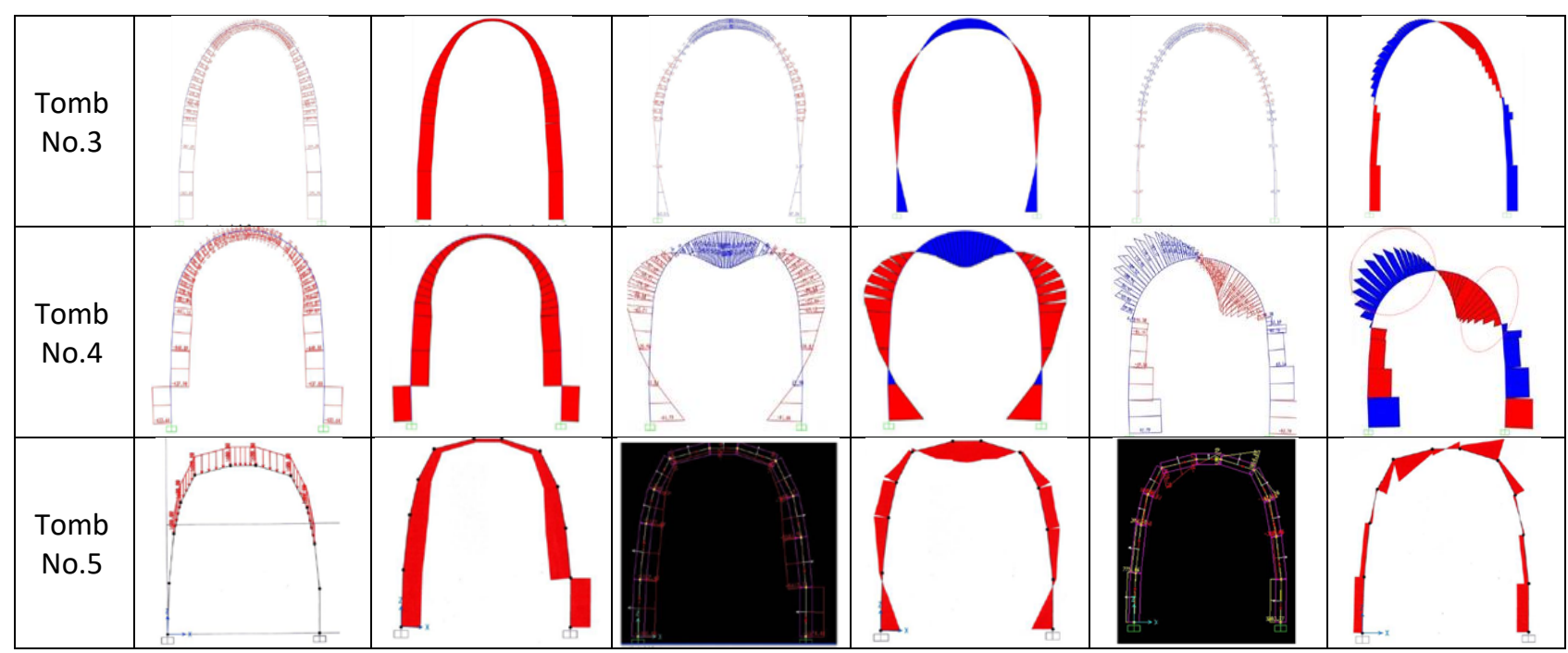

Based on the diagrams in Table 5, the following results were obtained:

- As clearly seen in the axial force diagrams, when the distributed load is affected by the structure, the maximum load is transmitted to the ground at the base of the walls.

- In all the bending moment diagrams, at the raising point of the vaults, the maximum bending force occurs and the shear force at the same point is zero. To control the structure against the bending force, it is important that the bending in the vaults turns into pressure force that the bricks can resist perfectly. However, in this case, the tension resistance decreases.

- According to the shear moment diagrams, the shear force is maximized at the edges over the vault. The only way to control the shear force due to the behaviour of the brick materials is to increase the thickness. This is done only where shear is maximum, which is fundamental to reduce the costs.

- As obviously seen in the bending moment and shear moment diagrams, shearing at the reinforced point are maximized.

- The vaults in all tombs were built in a similar way, except for the tomb number 4, where the vault was reinforced at another point.

Conclusions

The proper construction of the underground tomb vaults in the Chogha Zanbil area has ensured that the tombs still behave intact and healthy after thousands of years. The construction of high-resistance underground tombs by Elam architects has roots in their beliefs for afterlife. Based on the observations in the current study, the following conclusions can be drawn:

- Diagonal walls caused forces to be transmitted more desirably to the ground, compared to their vertical state. Walls of the four tombs were constructed diagonally from ground to the basement, which means that construction of the vault is started from ground's surface.

- The walls of tomb number 4 differ from other tombs and are closer to the vertical form. In fact, all the walls were reinforced at a close distance to the voussoir, with the exception of tomb number 4, where the reinforcement was almost close to the extrados. This difference is due to strengthening the other point of this vault, which caused the shear force to reach its maximum at the reinforced point of the the vault of tomb number 4 .

- The brickwork of the vaults in all five tombs is soldier with more resistance than the other two methods.

- All vaults have an excellent height that ensures high resistance.

Factors that increase the resistance of the underground tomb vaults include the following issues:

- Materials Layout: The bricks of tomb vaults are stringcourse and vertical, and additionally this brickwork method has high resistance compared to other methods.

- The Form of the Vault: The forms of the vaults of the tombs are cradle-shaped, sagittal and very high. As stated in the study, the forces tend to be vertical, and the resistance increases when the rise is long.

- Buttress: In many Iranian monuments, the thickness of the walls was increased to 3/1 to prevent the arch from deflecting. This was also essential to neutralize the tensile forces. In Chogha Zanbil Tombs, due to the formation of an arch on the ground, the arch top is surrounded by soil, acts like a buttress and prevents the arch from crumbling. 
- Integrity: The vaults were fully integrated from the floor to the ceiling and this integration increased the arch strength against the lateral forces.

- Type of the Mortar: The mortar between the bricks has good adhesion and strength as well as providing insulation (use of bitumen). Due to these features, there wasn't any falling or bulging of the bricks in the tombs.

- Molding: Usually, molding method was used in the vaults with vertical brickwork. Evidence of molds can be seen on the walls as a hole in the diameter of the wood molds. However, there is no molding mark on the walls of these tombs.

References

Afkhami, B. (2019). Phenomenology of chogha zanbi'l ziggurat. Journal of Ancient History and Archaeology. doi: 10.14795/j.v6i1.355

Amiet, P. (2018). Chogha Zanbil. In Oxford Art Online. doi:10.1093/gao/9781884446054.article.t017332

Amiet, P., \& Potts, D. T. (2008). The Archaeology of Elam: Formation and Transformation of an Ancient Iranian State. American Journal of Archaeology. doi:10.2307/507206

Besenval, R. (2000). Technologie de la voute dans l'orient ancien. (M. Habibi, Ed.). Tehran: Iran Cultural Heritage Organization (Research Center) in cooperation with the French association of Iranology in Iran.

Golabchi, M., \& Javani Dizchi, A. (2016). Iranian Architectural Technology. Tehran: Tehran University.

Heidari, B. (2010). Tomb No. 5 restoration plan (Chogha Zanbil). Islamic Azad University Central Tehran Branch.

Hinz, W. (1964). Das Reich Elam (Originalau). Stuttgart: W. Kohlhammer. Retrieved from https://books.google.com/books?id=SvAyAAAAMAAJ

Hosini, S. H. (2002). The method of using bitumen mortar in Chogha zanbil monument.

Koldwey, R. \& Johns, A. S. G. (1914). The excavations at Babylon. London: Macmillan and Co. Retrieved from https://www.worldcat.org/title/excavations-at-babylon/oclc/579700481

Majidzade, Y. (2008). The History and Civilization of Elam. Tehran: University Publication Center.

McMahon, A. \& Potts, D. T. (2001). The Archaeology of Elam: Formation and Transformation of the Ancient Iranian State. Journal of the American Oriental Society. doi:10.2307/606687

Naif A. H. (2015). Critical Assessment of the Barrel Vault Geometry and Structure of the Oldest Macedonian Tomb of Eurydice in Vergina. Mediterranean Archaeology \& Archaeometry, 15(2),143-162.

Pirnia, M. K. (1992). Dome Glossary. Athar Journal, 12(20), 140-152. Retrieved from journal.richt.ir/athar/article-1-393fa.html

Salehvand, Navid, Shishegar, A., \& Firoozmandi Shireh jin, Bahman. (2019). A Research on Tubular Glass Rods of UntashNapirisha Doors and Their Analysis by X-Rey Fluorescence Method. Pazhoheshha-Ye Bastan Shenasi Iran. doi:10.22084/nbsh.2017.12764.1560

Tavakoli, L. sadat. (2006). The plan of restoration and instauration of the underground tombs of medieval Eam is a case study of the tomb number 5. Islamic Azad University Central Tehran Branch.

Yordanov, V., Mostafavi, A., \& Scaioni, M. (2019). Distance-Training for image-based 3d modelling of archeological sites in remote regions. In ISPRS Annals of the Photogrammetry, Remote Sensing and Spatial Information Sciences. doi:10.5194/isprs-Archives-XLII-2-W11-1165-2019

Young, T. C., \& Ghirshman, R. (1969). Memoires de la Delegation Archeologique en Iran. Tome XXXIX. Mission de Susiane. Tchoga Zanbil (Dur-Untash). Vol. I. La Ziggurat. American Journal of Archaeology. doi:10.2307/503523

Zalaghi, A. (2018). Digging up the Past: Revisiting the Elamite Underground Vaulted Tombs at Tappeh 497 (KS 53 ?), Susiana Plain. Elamica, 8.

Zomorshidi, H. (2008). Vaults and Arches in Iranian Architecture. (S. Meshki \& M. Kazemi, Eds.) (First edit). Tehran: Urban Development and Revitalization Company of Iran press. 